\title{
Social transmission, tradition and culture in primates : from the epiphenomenon to the phenomenon
}

Bernard Thierry

\section{(2) OpenEdition}

Journals

Electronic version

URL: https://journals.openedition.org/tc/554

DOI: $10.4000 /$ tc.554

ISSN: 1952-420X

Publisher

Éditions de l'EHESS

\section{Printed version}

Date of publication: 1 November 1995

ISSN: 0248-6016

\section{Electronic reference}

Bernard Thierry, "Social transmission, tradition and culture in primates : from the epiphenomenon to the phenomenon", Techniques \& Culture [Online], 23-24 | 1995, Online since 07 December 2005, connection on 29 September 2022. URL: http://journals.openedition.org/tc/554 ; DOI: https://doi.org/ $10.4000 /$ tc. 554

This text was automatically generated on 29 September 2022

All rights reserved 


\section{Social transmission, tradition and culture in primates : from the epiphenomenon to the phenomenon}

Bernard Thierry 